\title{
Suggestions on Salary Structure Design of China's Private Enterprise
}

\author{
Haisheng Liu $^{1, a^{*}}$ and Mingwei Ma ${ }^{2, b}$ \\ ${ }^{1}$ School of Business Administration,Changchun Sci-Tech University, Changchun,China,130600 \\ ${ }^{2}$ Faculty of Continuing Education, Communication University of China, Beijing, China, 100024 \\ acalloftheduty1988@hotmail.com, b arbey33163@163.com \\ * The Corresponding Author
}

Keywords: Business management; Salary system; Compensation design; Private enterprise

\begin{abstract}
The salary system of private enterprises directly determines the benefit of the enterprise, and the design of a scientific and effective salary system is the key to the development and survival of the enterprise. Through the analysis of the existing salary system of private enterprises in China, this paper draws a conclusion that there are problems and shortcomings in the salary system of private enterprises. Combined with the salary system of a catering enterprise, aiming at improving employee satisfaction, this paper puts forward a salary optimization strategy that emphasizes enterprise welfare, defines salary objectives, attaches importance to special talents and pays attention to fairness.
\end{abstract}

\section{Introduction}

As an important part of modern China's economic system, private enterprises have made more and more significant contributions to China's economic growth [1]. In the face of the sluggish international market demand and the turbulent domestic financing environment, the development of private enterprises is faced with many challenges. The enterprise is composed of employees and managers. Employees' satisfaction with their jobs largely determines the rise and decline of enterprises, and the salary system is an important factor affecting employee satisfaction [2,3]. However, it has little effect to reduce the mobility of excellent employees by improving the remuneration. Therefore, under the premise of reasonable control of operation cost, many private enterprises have established the salary system with their own characteristics. Through optimizing the salary and human resource management, the enterprise can achieve sustainable development $[4,5]$.

\section{Analysis on the Salary Design of Private Enterprises}

The private enterprises in China are at the stage of rapid development, and they have also exposed some drawbacks while achieving brilliant achievements. Through investigation, the author has found that there are some problems in salary management of private enterprises in China. First, the salary model is too extreme. The salary management concept of most private enterprises has not been updated with the development of the enterprise, and it is still stagnant in the thinking taking the short-term performance as the goal in the early stages of enterpreneurship. High fixed and high elastic extreme modes are often adopted in the salary design of private enterprises. For the salesmen, the "broadband salary" which overemphasizes the performance is adopted. For the production and execution employees, the salary is often lower. For administrative, management, financial and other general office work posts, the fixed salary is taken. The second is the improper specialization and homogenization. As for the talents that are urgently needed by the enterprises, such as technical personnel or managers, private enterprises tend to give fairly generous treatment. In this way, high paid talents will have a huge salary gap with his colleagues, which will affect the team morale and unity to a certain extent. Finally, internal salaries are ignored. "Internal salaries" are all kinds of rewards that do not show in the form of currency. It is mainly manifested in the fact that although some employees enjoy a high salary, they lack the sense of achievement and the sense of belonging to the company. Therefore, the unreasonable salary system of private enterprises can not be recognized by the employees, and is unfavorable to the long-term development of the enterprises [6]. 


\section{Study on the Optimization of the Salary System of Private Enterprises}

Through the analysis of the salary system of a catering enterprise A, the following five points are put forward to improve the traditional salary system:

Multiple Incentive Parallel System. The idea that money can motivate employees and improve organizational performance is one of the most important principles for the design of the salary system for a long time. This theory has some limitations. The hypothesis of "monetary incentive theory" is based on the basis that "the needs of employees can only be met through money". But in fact, the actual needs of employees are diverse and can not be motivated solely by money. Take a catering enterprise A as an example, the company stipulates that the employees can enjoy a certain holiday according to the position level and they can receive the commemorative prizes provided by the enterprise on festivals and birthdays. Although these rewards can be paid to employees in the form of cash, it is clear that the enterprise $A$ has achieved a better incentive effect $[7,8]$. It can be seen that the comprehensive use of different forms of incentive is more effective than simple "monetary incentives".

Constructing the Target Oriented Salary System. The goal of the salary system is to attract and influence the employees in a certain budget and to maintain the satisfaction of the employees to the enterprise. A reasonable salary system should meet the requirements of the enterprise's human resource strategy, enable enterprises to retain excellent employees, and guide employees to recognize the goals of enterprises and spontaneously help enterprises achieve the goals. Enterprise A, referring to its own operational objectives that "motivate employees to serve customers and retain excellent employees", customized the salary system as shown in Figure 1, figure 2.

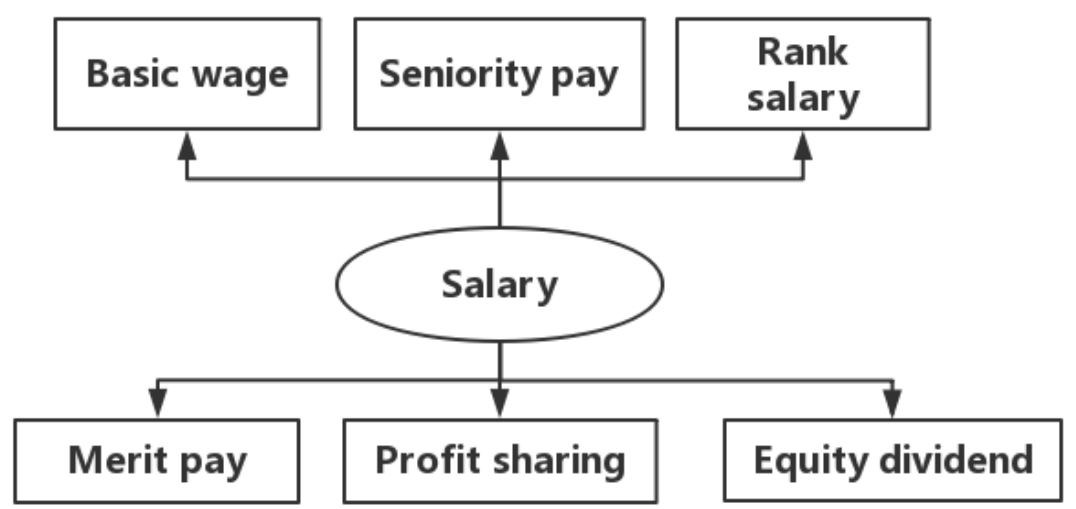

Figure 1. Summary of enterprise salary system

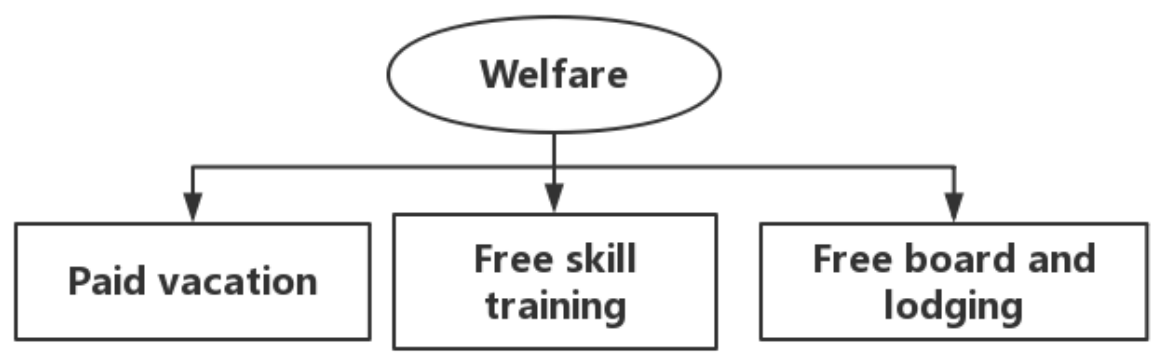

Figure 2. Enterprise welfare 
Table 1 The salary structure of a catering enterprise A

\begin{tabular}{|c|c|c|c|c|c|c|}
\hline Grade salary & $\begin{array}{l}\text { Basic } \\
\text { wage }\end{array}$ & $\begin{array}{c}\text { Seniority } \\
\text { pay }\end{array}$ & $\begin{array}{l}\text { Profit } \\
\text { sharing }\end{array}$ & $\begin{array}{l}\text { Rank } \\
\text { salary }\end{array}$ & Merit pay & $\begin{array}{l}\text { Equity } \\
\text { dividend }\end{array}$ \\
\hline New employee & $\sqrt{ }$ & $\sqrt{ }$ & & & $\sqrt{ }$ & \\
\hline $\begin{array}{c}\text { First-degree } \\
\text { employee }\end{array}$ & $\sqrt{ }$ & $\sqrt{ }$ & & $\sqrt{ }$ & $\sqrt{ }$ & \\
\hline $\begin{array}{c}\text { Second-degree } \\
\text { employee }\end{array}$ & $\sqrt{ }$ & $\sqrt{ }$ & & $\sqrt{ }$ & $\sqrt{ }$ & \\
\hline $\begin{array}{c}\text { Third-degree } \\
\text { employee }\end{array}$ & $\sqrt{ }$ & $\sqrt{ }$ & & $\sqrt{ }$ & $\sqrt{ }$ & \\
\hline $\begin{array}{l}\text { pacesetter } \\
\text { employee }\end{array}$ & $\sqrt{ }$ & $\sqrt{ }$ & $\sqrt{ }$ & $\sqrt{ }$ & $\sqrt{ }$ & $\sqrt{ }$ \\
\hline $\begin{array}{c}\text { Meritorious } \\
\text { employee }\end{array}$ & $\sqrt{ }$ & $\sqrt{ }$ & $\sqrt{ }$ & $\sqrt{ }$ & $\sqrt{ }$ & $\sqrt{ }$ \\
\hline $\begin{array}{c}\text { Middle } \\
\text { managers }\end{array}$ & $\sqrt{ }$ & $\sqrt{ }$ & $\sqrt{ }$ & $\sqrt{ }$ & $\sqrt{ }$ & $\sqrt{ }$ \\
\hline
\end{tabular}

In combination with Table 1, it can be found that the salary system of a catering enterprise A includes two parts, namely, salary and welfare. In terms of salary, the enterprise A implements the model of basic wage + seniority pay + profit sharing + range wage + employee stock ownership. The service staff in the enterprise A are divided into different levels. The salary structure based on basic wage+seniority pay is adopted. For the pacesetter staff and meritorious staff, the salary mode based on basic wage+profit sharing is adopted. For the middle-level manager, the mode of basic wage+merit pay+profit sharing is adopted. This design enables excellent employees to get bonus and range salary. They have a gap with the salaries of employees with flat performance, so as to reduce the turnover of excellent employees. The employees in the enterprise A can enjoy a variety of welfare from the basic board and lodging to the paid annual leave, to the free participation in the development training organized by enterprises $[9,10]$. Through the welfare, enterprise A increases employees' sense of belonging and stimulates employees to contribute more actively to the development of the enterprise.

Paying Attention to Technical Personnel and Middle Management Team. The design of salary system should focus on middle-level managers and core technicians. The performance output, incentive level, salary satisfaction and flow rate of the two types of employees should be the key weight index of the design of the enterprise salary system. On the one hand, middle-level managers are familiar with the management of enterprises, and on the other hand, they play a role of guidance and example for their subordinates. The core technicians are typical "knowledge workers". Their loyalty to their own profession makes them always look for an employer who can make the best of their value. Therefore, private enterprises should ensure that their core technicians can play their own skills in the work and have a certain space for growth.

Taking the Employee Satisfaction as the Goal. Management scientists believe that the enterprise performance is derived from employee satisfaction. However, the employee's satisfaction with salary comes from four dimensions: salary level, salary structure, salary system and salary form satisfaction. Therefore, the private enterprises can evaluate their salary system by the satisfaction of employees. The service enthusiasm of the employees in enterprise A is closely related to their salary system. When 
employees have higher salary satisfaction, the turnover rate of employees will be greatly reduced. Enterprise A has changed part of its monetary salary into employee benefits, which is more diverse than competitors in the salary structure. For the salary system, the enterprise A provides considerable salary growth space for employees. By rank salary and profit sharing, the enterprise combines employees' salary with corporate profits to make employees focus on improving their performance. As shown in Fig.3, after optimizing the salary system of enterprise A, the employee satisfaction increases by $19 \%$, the dissatisfaction is reduced by $12 \%$, and the enterprise profit on year-on-year basis increases by $15 \%$.

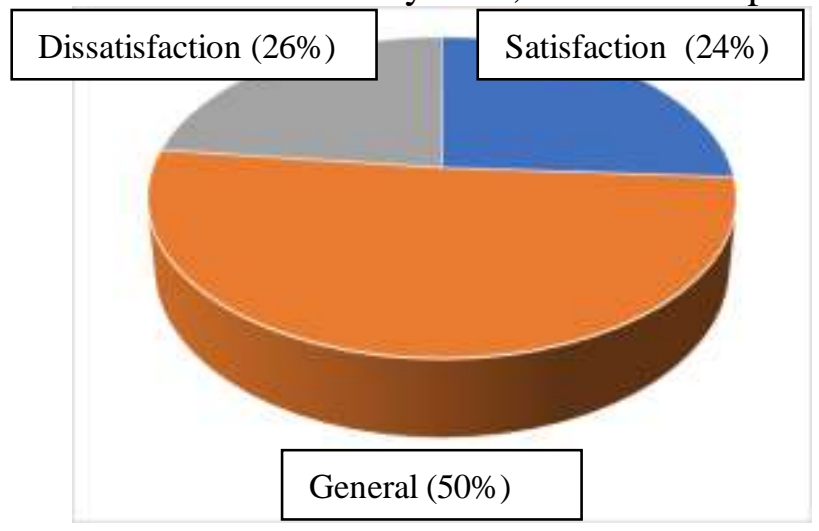

(a) Before

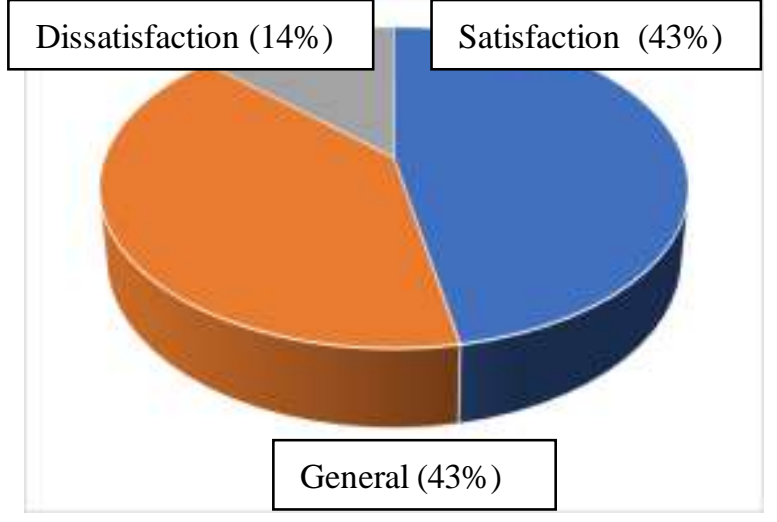

(b) After

Figure 3. Comparison of employees' satisfaction before and after optimizing the salary system

Paying Attention to the Fairness of the Salary System. The enterprise should pay attention to the fairness of the system. If the employees think salary system is unfair, they may don't have the enthusiasm to increase the performance. Under the new normal economic situation, employees can have more access to the labor market information, and gradually increase their awareness of their own values. Private enterprises should pay attention to the external equity and internal equity of the salary of their core posts, and prevent the turnover of employees.

\section{Summary}

The core of the salary management of the private enterprises is to design a reasonable salary system. Enterprises should set up a system that includes multiple incentive elements, makes visible salary and recessive salary develop harmoniously, protects core staff salaries and maintains salary fairness, so as to promote the "qualitative change" of salary management. Excellent salary system should fit in with corporate culture and business objectives, and guide employees to focus on their performance improvement and make greater contributions to enterprises, so as to achieve a win-win situation between employees and enterprises.

\section{Acknowledgements}

The work reported in this paper is supported by the project of Educational Science Planning in Jilin (CZI2019).

\section{References}

[1] Armstrong M, Page K. A Handbook of Human Resource Management Practice ,7th ed., Kogan Page Ltd, London ,2014,pp. 100-112.

[2] Guiso L, Sapienza P, Zingales L. The value of corporate culture [J]. Journal of Financial Economics, 2015, 117(1):60-76.

[3] Kosfeld M, Siemens F A V. Competition, cooperation, and corporate culture[J]. Rand Journal of Economics, 2011, 42(1):23-43. 
[4] Englmaier F, Leider S. Contractual and Organizational Structure with Reciprocal Agents[J]. American Economic Journal Microeconomics, 2012, 4(2):146-183.

[5] Charness G, Kuhn P. Chapter 3 - Lab Labor: What Can Labor Economists Learn from the Lab? [J]. Social Science Electronic Publishing, 2011, 4:229-330.

[6] Kosfeld M, Siemens F A V. Worker Self-Selection and the Profits from Cooperation[J]. Journal of the European Economic Association, 2011, 7(2-3):573-582.

[7] Bauer R, Hann D. Corporate Environmental Management and Credit Risk[J]. Social Science Electronic Publishing, 2010.

[8] Peng L. Individual Choice and Reputation Distribution of Cooperative Behaviors among Heterogeneous Groups. Chaos, Solitons \& Fractals, 2015, 77: 39-46.

[9] Karim K, Lee E, Suh S. Corporate social responsibility and CEO compensation structure[J]. Advances in Accounting, 2017.

[10] Rekker S A C, Benson K L, Faff R W. Corporate social responsibility and CEO compensation revisited: Do disaggregation, market stress, gender matter?[J]. Journal of Economics \& Business, 2014, 72(9):84-103.

[11] Hao Z, Xu G, Zhang Y, et al. Salary Management System for Small and Medium-sized Enterprises[C]// International Conference on Circuit and Signal Processing \& 2010 Second Iita International Joint Conference on Artificial Intelligence. 2010:2255-2260. 